But then the darker side of this history reveals itself in the emergence of tainted blood drawn from donors in search of cash. A dismaying chapter in this history involves blood collection for money in Central America and other underdeveloped countries from people in desperate financial need. The problems of hepatitis transmission were soon overshadowed by the contamination of the blood supply by the human immunodeficiency virus (HIV).

Then there is the frightening tale of the deadly triumph of the free market. When the Community Blood Bank of Kansas City, Missouri, became the favoured source of blood for physicians because a local commercial blood-donor centre was collecting contaminated blood, the United States Federal Trade Commission accused the physicians of illegal conspiracy to restrain free trade! A fine of $\$ 5,000$ a day was imposed until blood was purchased from the contaminated commercial source.

The last part of the book looks at the now twice-told tale of HIV contamination of anti-haemophilic factor, and the bitter resentments and ugly legal squabbles that ensued. The former French prime minister Laurent Fabius was acquitted only a few weeks ago - to the dismay of many, in what Starr calls cathartic national breast-beating.

Many significant contributors to blood banking do not appear in this book. There is no mention of Allen Latham, who at Cohn's instigation invented the blood-cell separator, the so-called Latham bowl. The monumental struggle of Harvard surgeon Carl Walter with the US Food and Drug Administration to get blood out of breakable glass bottles and into malleable plastic bags is given only brief mention. And the late Wallace Coulter, who standardized blood counting worldwide with his Coulter counter, invented in the basement of a Chicago boarding-house using the Cellophane wrapper from a pack of Lucky Strike cigarettes during the Second World War, gets no space.

There are many more books to be written about all this. And the blood supply is once again safe - until the next unknown bloodborne virus creeps up on us.

Fred S. Rosen is in the Department of Pediatrics, Harvard Medical School, Longwood Avenue, Boston, Massachusetts 02115, USA.

\section{Storm-chaser reaps the whirlwind}

\section{Tornado Alley: Monster Storms of the Great Plains \\ by Howard B. Bluestein \\ Oxford University Press: 1998.170 pp. \$35, $\mathfrak{E} 17.99$}

\section{Roger A. Pielke Sr}

Howie Bluestein is the man who made 'storm-chasing' scientifically acceptable. A pioneer in the field observation and measurement of tornadoes and tornadic thunderstorms, he blends history and science with his personal experiences in a book that will be enjoyed by anyone who is interested in these intense atmospheric whirlwinds. It should also help clear up any misunderstandings that resulted from seeing the recent film Twister!

Though the text is very detailed in places, non-specialists can safely skim the technical sections without losing the point. The use of degrees Fahrenheit and feet may be annoying to some readers, but the numbers can easily be converted to metric units.

The book analyses other people's experiences of tornadoes as well as drawing on

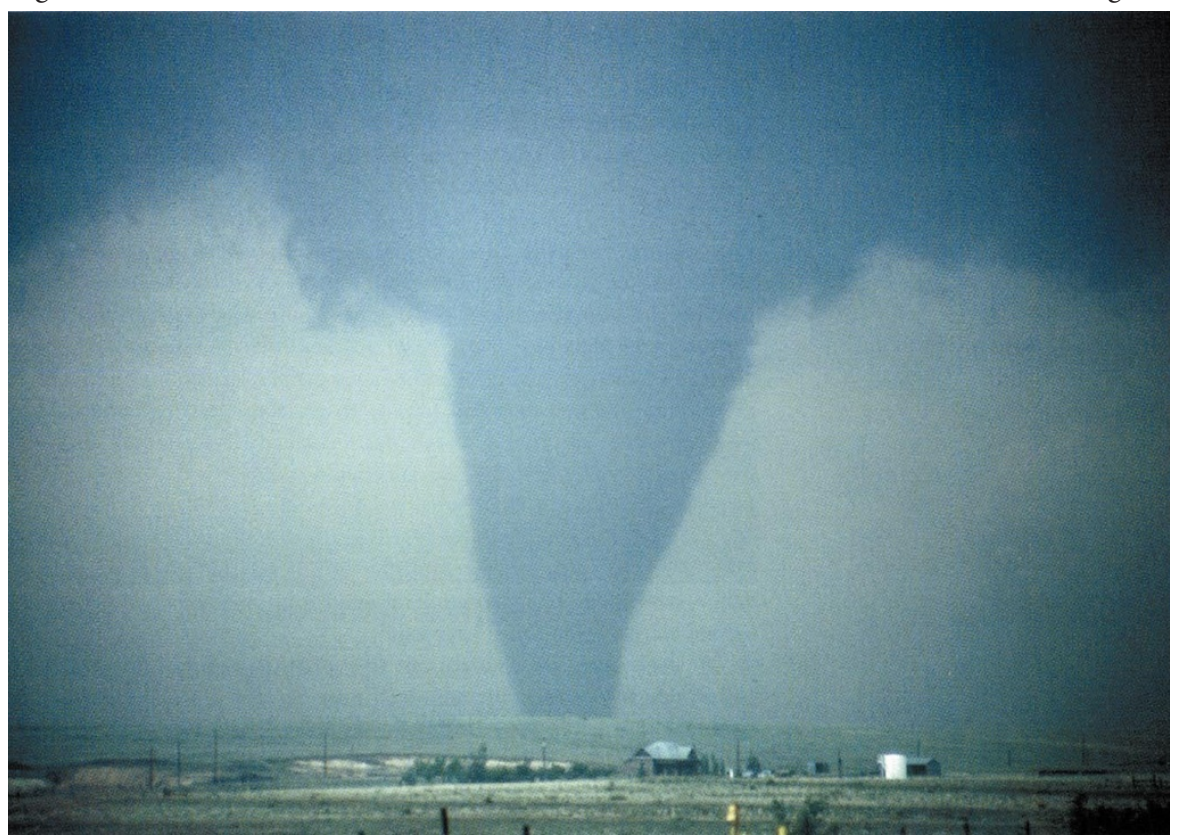

Threatening clouds: a tornado in its mature phase looms over the town of Canadian, Texas, in 1986.
Bluestein's personal perspective. It includes a useful discussion of the Fujita scale of intensity, which was introduced by Ted Fujita of the University of Chicago and has now become accepted by the public.

Bluestein looks at the use of computers to simulate tornadic thunderstorms: the correspondence between computer modelling and the actual behaviour of thunderstorms is remarkable. Unfortunately, he does not mention some important recent work by Louie Grasso of the US National Oceanic and Atmospheric Administration and Cathy Finley of the University of Northern Colorado. These two have, separately, simulated the development of actual tornadoes - Finley has even simulated the development and dissipation of their suction vortices. Bluestein also overlooks the modelling work of researchers such as Bob Walko while at the University of Oklahoma, and Conrad Ziegler at the National Severe Storms Laboratory.

Because of the major role he has played in field campaigns studying 'Tornado Alley' in the Great Plains of the United States, Bluestein is often seen in television shows on this now-popular subject. In fact, tornadoes have a long history on our screens. Bluestein's TOTO - the Totally Totable Observatory, a canister packed with meteorological instruments and used in some of his earlier field campaigns - was named after Dorothy's dog in The Wizard of Oz. (Twister was based on attempts to insert these instruments into the path of tornadoes.) The discussion of TOTO in this book is a pleasure to read.

Readers interested in an overview of measurement systems will appreciate Bluestein's explanations of facilities spanning the size range from helicopters and remotely piloted vehicles to the latest model TOTO II. Portable rawinsondes and Doppler radars, Doppler lidars, millimetrewavelength radars and airborne Doppler radars - each of these offers a unique way to monitor tornadoes.

What next? Bluestein's speculation on the future of tornado research, as one of the scientific leaders in this field, makes important reading. For his part, he is likely to continue to play an active role in their investigation.

For further reading, the book lists relevant websites and other sources of tornado information. The outstanding set of videos prepared by the Tornado Project in St Johnsbury, Vermont, should be added to the list (http://www.tornadoproject. com).

In conclusion, this book by an internationally recognized expert in his subject is an enjoyable read. The scientific understanding of tornadoes is increasing all the time, and Bluestein masterfully weaves his experiences together with his insights into this constantly evolving field of research.

Roger A. Pielke Sr is in the Department of Atmospheric Science, Colorado State University, Fort Collins, Colorado 80523, USA. 